NBER WORKING PAPER SERIES

\title{
THE STOCK MARKET CRASH OF 2008 CAUSED THE GREAT RECESSION: THEORY AND EVIDENCE
}

\author{
Roger E.A. Farmer \\ Working Paper 17479 \\ http://www.nber.org/papers/w17479 \\ NATIONAL BUREAU OF ECONOMIC RESEARCH \\ 1050 Massachusetts Avenue \\ Cambridge, MA 02138 \\ October 2011
}

This paper was prepared as a Plenary Address to the 17th International Conference in Economics and Finance, held at the Federal Reserve Bank of San Francisco, June 29th-July 1st 2011. I would like to thank the Society for Computational Economics and the Federal Reserve Bank of San Francisco for supporting this event and the organizers, Richard Dennis and Kevin Lansing, for inviting me to present my work. I would also like to thank Dmitry Plotnikov of UCLA for his invaluable research assistance and to acknowledge the input of seminar participants at Academia Sinica, the Federal Reserve Banks of Atlanta and Dallas, Georgetown University, Taiwan National University, UCLA and the University of California San Diego. I would also like to thank Cars Hommes and an associate editor of this journal for their comments on the paper. The views expressed herein are those of the author and do not necessarily reflect the views of the National Bureau of Economic Research.

NBER working papers are circulated for discussion and comment purposes. They have not been peerreviewed or been subject to the review by the NBER Board of Directors that accompanies official NBER publications.

(C) 2011 by Roger E.A. Farmer. All rights reserved. Short sections of text, not to exceed two paragraphs, may be quoted without explicit permission provided that full credit, including $(\mathbb{C}$ notice, is given to the source. 
The Stock Market Crash of 2008 Caused the Great Recession: Theory and Evidence

Roger E.A. Farmer

NBER Working Paper No. 17479

October 2011, Revised January 2012

JEL No. E0,E2

\begin{abstract}
This paper argues that the stock market crash of 2008, triggered by a collapse in house prices, caused the Great Recession. The paper has three parts. First, it provides evidence of a high correlation between the value of the stock market and the unemployment rate in U.S. data since 1929. Second, it compares a new model of the economy developed in recent papers and books by Farmer, with a classical model and with a textbook Keynesian approach. Third, it provides evidence that fiscal stimulus will not permanently restore full employment. In Farmer's model, as in the Keynesian model, employment is demand determined. But aggregate demand depends on wealth, not on income.
\end{abstract}

Roger E.A. Farmer

UCLA

Department of Economics

Box 951477

Los Angeles, CA 90095-1477

and NBER

rfarmer@econ.ucla.edu 


\section{Introduction}

This paper is about the relationship between the stock market and the unemployment rate. It has three parts. First, I establish that there has been a high correlation between unemployment and the stock market in U.S. data since 1929. I use post-war quarterly data to estimate a bivariate time series model of unemployment and the real value of the stock market and I show that this model remained structurally stable before and after 1979 .

Second, I compare three simple theoretical models of the economy; a classical model, a Keynesian model and a "Farmerian model", based on a series of recent books and papers (Farmer, 2008, 2009, 2010a,b,c,d, 2011). I evaluate the ability of each of these models to explain the Great Recession of 2008 and I argue that the Farmerian model provides the most plausible explanation of events.

Third, I explain why I have advocated (Farmer, December 30th 2008) a policy of asset market intervention to restore full employment rather than a traditional Keynesian policy of fiscal stimulus. I present some evidence which shows that the Keynesian consumption function has not remained stable in the post-war period and I explain that evidence by showing that increases in government purchases since 1929 have been accompanied by offsetting changes in private consumption expenditure. The behavior of household consumption is consistent with the work of Friedman (1957) who showed that consumers respond to permanent income, or wealth, and not to transitory income.

My work explains why high unemployment can persist for long periods of time. Although my explanation is rooted in Keynesian ideas, it goes beyond The General Theory (Keynes, 1936) by providing an original microfounded explanation for labor market failure. Unlike the new-Keynesian version of The General Theory, my explanation of recessions does not rely 
on the assumption that prices are sticky. ${ }^{1}$

The paper is organized as follows. Section 2 presents a brief review of related literature. Sections 3, 4 and 5 present empirical evidence on the relationship between the stock market and unemployment in U.S. data. Section 6 evaluates that evidence in the light of three alternative economic models and in Sections 7 and 8 I explain why I favor my approach over alternative classical and Keynesian models. Section 9 provides a short conclusion.

\section{Wealth and Unemployment in the Litera- ture}

Much recent work in empirical macroeconomics analyzes data that have been detrended with the Hodrick-Prescott filter (Hodrick and Prescott, 1997). Because it removes a different trend from each series, the HP-filter masks an important correlation between wealth and unemployment that operates at low to medium frequencies. In my work, I detrend data by dividing nominal consumption and nominal wealth by the money wage. The resulting detrended consumption and wealth series are very persistent and highly correlated with unemployment. My focus in this paper is on this correlation.

Empirical work by Lettau and Ludvigson (2004) found a low-frequency connection between consumption and wealth and, in a recent extension of their earlier work, Lettau and Ludvigson (2011) provide a statistical model of consumption, wealth and labor earnings as non-stationary time series that are cointegrated. In this paper I show that wealth and unemployment have a similar representation as non-stationary cointegrated time series and I provide a theory that connects all of these pieces together.

The connection between stock market wealth and unemployment was recognized by Phelps (1999) who pointed out that the stock market boom of

\footnotetext{
${ }^{1}$ Galí (2008) provides a good introduction to the new-Keynesian paradigm.
} 
the 1990s was accompanied by a reduction in the unemployment rate. Fitoussi, Jestaz, Phelps, and Zoega (2000) found a similar correlation between the stock market and unemployment for a variety of European countries. Following Phelps (1999) and Hoon and Phelps (1992), these authors explained this connection using Phelps' (1994) structuralist model of the natural rate of unemployment. In Phelps' model, expectations of future profits cause firms to invest in customer relationships and employee training.

In contrast, the theory I develop in this paper explains the connection between stock market wealth and unemployment with a model of multiple equilibria. In my work, any unemployment rate can be a steady state equilibrium and changes in aggregate demand have a permanent effect on the equilibrium unemployment rate. $^{2}$

In the model I describe in this paper, labor is continually fired and rehired. As a consequence of this simplifying assumption, the price of capital and the value of the stock market are the same variable. In the data (see for example the paper by Gomme, Ravikumar, and Rupert (2011)), they have very different time-series properties and the stock price is much more volatile than the price of capital. In the full dynamic version of the model developed in Farmer (2011), unemployment is a state variable of the firm, similar to the capital stock. Here, the stock price will differ from the price of capital. It is an open question as to whether the more general model can replicate the volatility of the stock price that we see in the data.

\footnotetext{
${ }^{2}$ My explanation for persistent unemployment is closer to the models of hysteresis described by Blanchard and Summers $(1987,1986)$ and Ball (1999) than the structuralist model of Phelps although the theoretical foundation for persistent unemployment in my work is very different from the one provided in those papers. Models based on newKeynesian economics (see Galí and Gertler (1999)), cannot account for persistent unemployment.
} 


\section{$3 \quad$ Wealth and Aggregate Demand}

Tangible assets in the U.S. are held in the form of factories, machines and houses. Factories and machines are equal to roughly three times GDP; residential real estate comprises an additional two times GDP.

Figure 1 shows the history of these two components of tangible assets beginning in the first quarter of 1929 and ending in the first quarter of 2011. The stock market variable is the value of the S\&P 500 divided by a measure of the money wage. When a nominal series is detrended in this way I will say that it is measured in wage units. ${ }^{3}$ The measure of housing wealth is my own estimate, constructed as follows.

I multiplied Shiller's historical house price index by the U.S. population and I divided it by the money wage. I multiplied the data by population because I do not have a series on the housing stock for the entire period. My estimate is based on the assumption that the ratio of people to houses was constant. ${ }^{4}$

To construct the wealth index reported in Figure 2, I took 0.072 times my housing wealth variable and I added it to 0.0052 times the $\mathrm{S} \& \mathrm{P}$ in wage units. These weights were chosen to give a wealth index that is $2 / 5$ housing and $3 / 5$ stocks, and that has a mean of 100 over the period from 1929 through 2011. The proportions of $2 / 5$ and $3 / 5$ were chosen to match the proportions of housing to other tangible assets in Federal Reserve Flow of Funds data. ${ }^{5}$

\footnotetext{
${ }^{3}$ The use of wage units to detrend data is a novel technique that I developed and explained in my book Expectations Employment and Prices Farmer (2010b). The money wage increases because of growth in the real economy and because of inflation. Detrending by the money wage removes both sources of growth and renders nominal series stationary.

${ }^{4}$ Robert Shiller's housing data are available quarterly from 1953q1 through 2011. Before that date I interpolated the annual series to provide quarterly estimates from 1929. Shiller's data are available at 'http://www.econ.yale.edu/ shiller/'.

${ }^{5} \mathrm{I}$ use the S\&P as a measure of wealth because it is available back to 1929. My empirical work is robust to the use of the measure of household wealth held as stocks reported in the Federal Reserve Flow of Funds data. That measure moves closely with the S\&P500 in the post-war period.
} 
Housing Wealth and Stock Market Wealth Since 1929

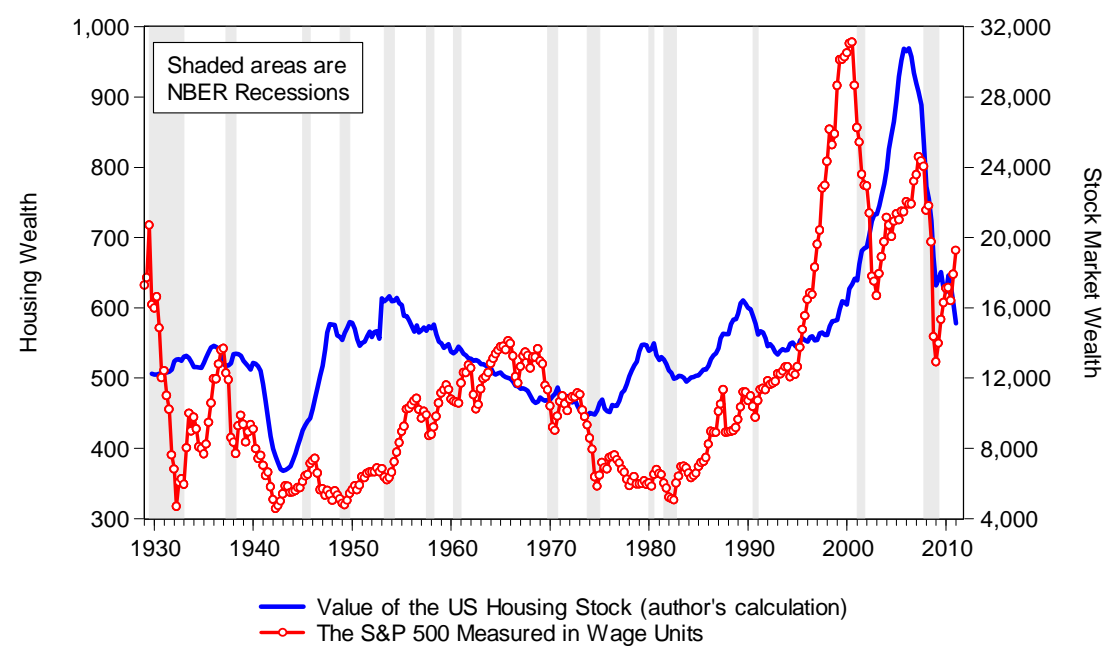

Figure 1: Housing and the Stock Market

Unemployment and Wealth During the Great Depression

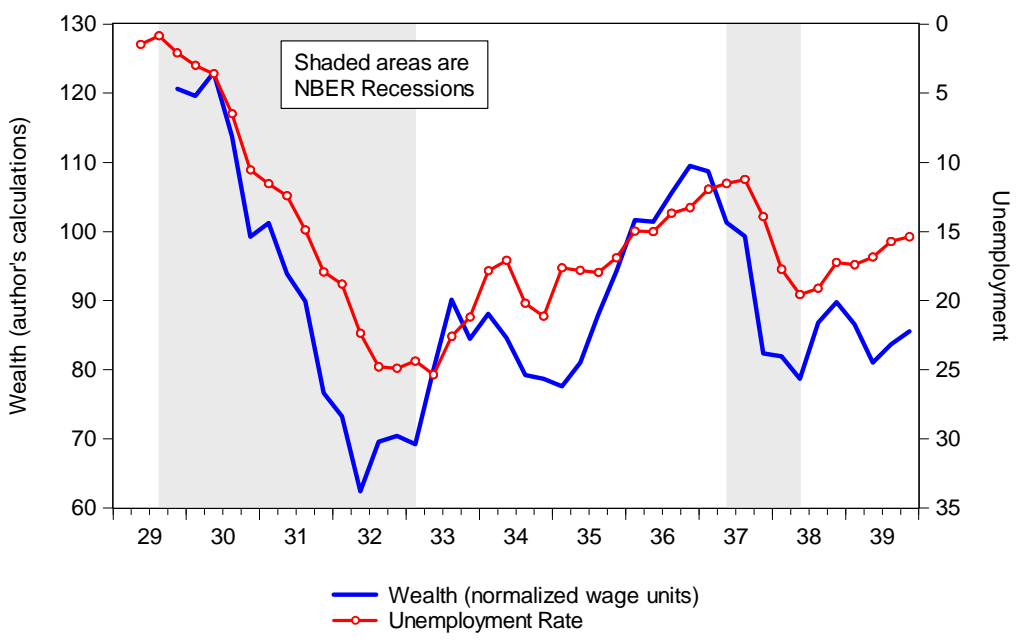

Figure 2: Unemployment and Wealth in the Great Depression 
Unemployment and Housing Wealth During the Great Recession

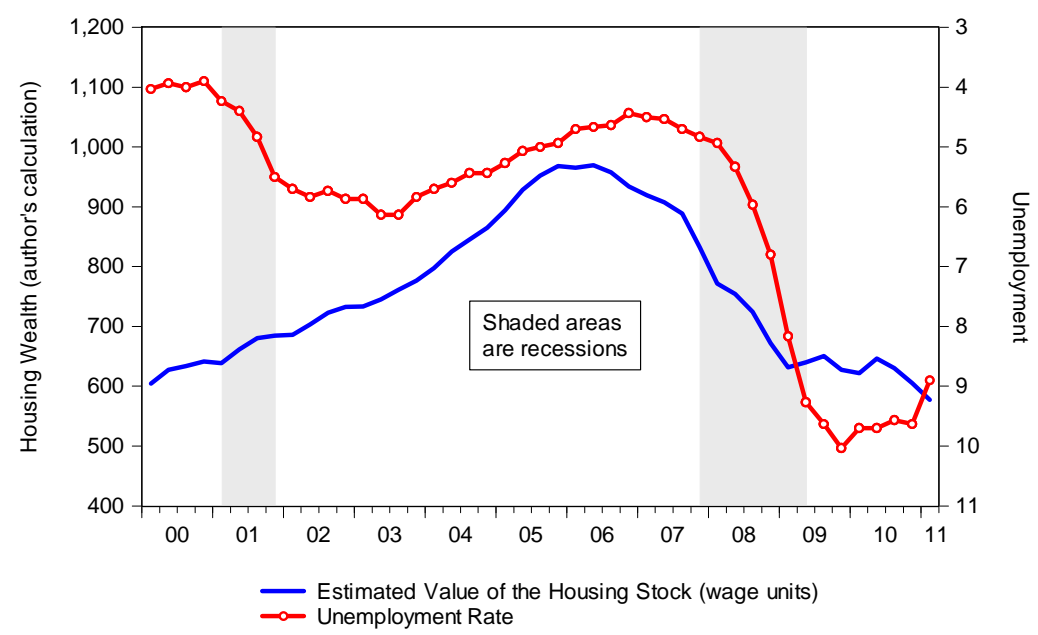

Figure 3: Unemployment and Housing

Unemployment and the Stock Market

During the Great Recession

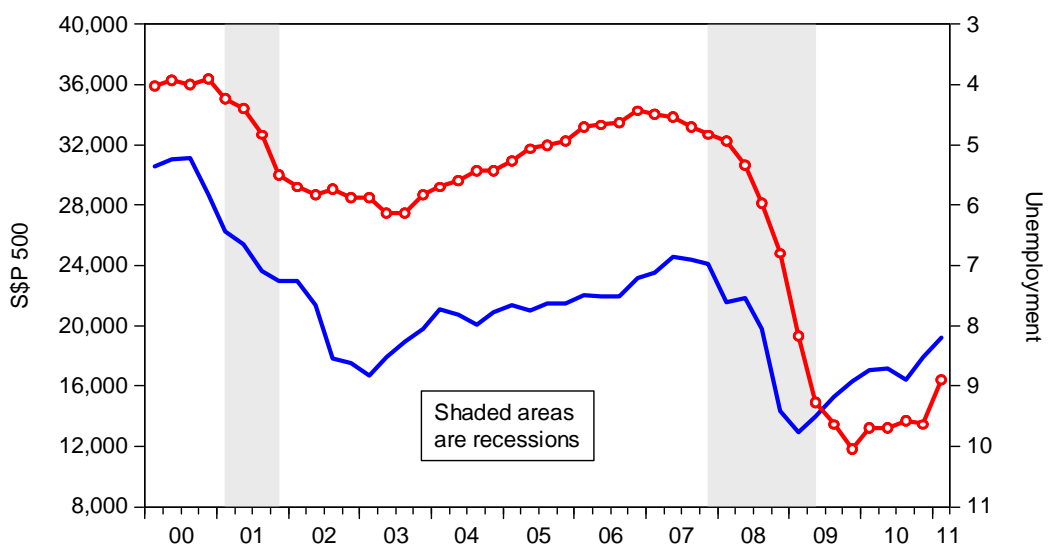

The S\&P 500 Measured in Wage Units

- - Unemployment Rate

Figure 4: Unemployment and the Stock Market 
I want to draw attention to two episodes: the Great Depression and the Great Recession. Figure 2 plots an index number of the real value of wealth on the left axis against the unemployment rate on the right axis for data during the Great Depression. This figure shows a strong correlation (the correlation coefficient is -0.88) between wealth and unemployment.

Figures 3 and 4 illustrate the behavior of wealth and unemployment during the Great Recession. I have reported housing and stock market wealth separately for this period because the collapse of the real value of residential real estate was an important source of changes in aggregate demand. A popular, and plausible account of these events, is that the collapse in house prices caused the recession.

The evidence in favor of this proposition is based on timing. The value of residential real estate peaked in the second quarter of 2006 and unemployment began to increase six months later in the fourth quarter of 2006. The stock market moved later, peaking in the third quarter of 2007.

In my interpretation of these events, the values of houses, factories and machines is determined by business and consumer confidence. In recent work (Farmer, 2011) I have shown how an explosive asset price path can persist as an equilibrium. In my view, the house price crash that began in 2006, was triggered by a shift in beliefs. Households lost confidence in the sustainability of continued house price increases and the economy shifted from a dynamic equilibrium in which house prices were growing explosively, to a new steady state equilibrium in which house prices are lower and unemployment higher. This new steady state can potentially be sustained for ever.

The fall in the value of residential and commercial real estate triggered a secondary collapse in financial assets whose value was collateralized by real estate wealth. The collapse in financial wealth triggered a stock market crash and households sustained a large drop in permanent income. They responded by increasing their savings and reducing consumption demand. The reduction in demand caused businesses to lay off workers and it triggered 
a drop in business income that validated the initial collapse in confidence. The 2008 financial crisis was a self-fulfilling prophecy.

\section{The Stock Market and Unemployment Since WWII}

The correlations between wealth and unemployment that I have reported for the Great Depression and the Great Recession are interesting. But a connection between wealth and unemployment that holds only during certain decades is not one that provides a sound basis on which to build an economic theory. We need to investigate more carefully, the connection between wealth and unemployment over a longer time horizon. That is the purpose of this section.

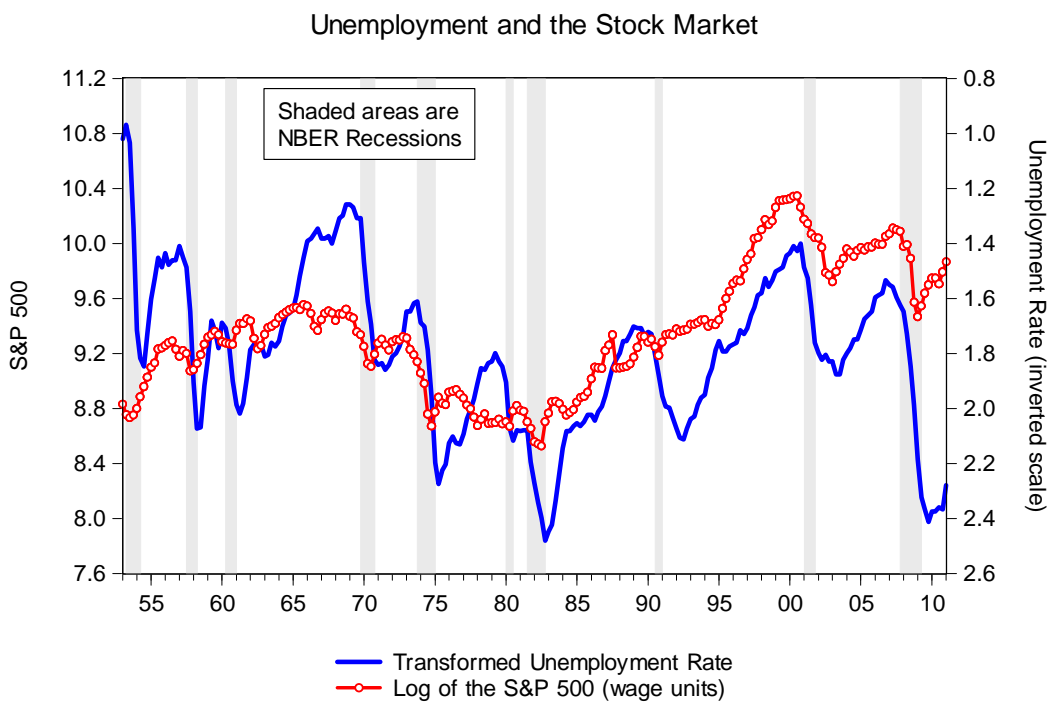

Figure 5: Unemploymant and the Stock Market Since 1953

I will focus here on the connection between unemployment and the stock market. Although housing was an important factor in the 2008 recession, 
house price declines did not precede any of the previous ten post-war recessions and it was not until the stock market began to decline in October of 2007 that the U.S. moved into recession. Stock price movements, on the other hand, show a stable relationship with unemployment over the entire post-war period.

Figure 5 shows the relationship between unemployment and the stock market from 1953q1 through 2011q1. I have taken the logarithm of the S\&P500, measured in wage units, and the logarithm of a logistic transformation of the percentage unemployment rate. These transformations lead to new variables that are unbounded above and below. This an important property since there is evidence that the two transformed variables are nonstationary but cointegrated and in order for a series to be non-stationary it must be able to increase or decrease without limit, independently of its current value.

\begin{tabular}{c|cc|cc|} 
& \multicolumn{2}{|c|}{$1953 q 1--1979 q 3$} & \multicolumn{2}{|c|}{$1979 q 4--2011 q 1$} \\
\hline dependent & $p$ & $u$ & $p$ & $u$ \\
variable & Rsq & 0.99 & Rsq & 0.96 \\
$\mathrm{p}(-1)$ & 1.41 & -0.33 & 1.30 & -0.26 \\
& $(0.09)$ & $(0.10)$ & $(0.09)$ & $(0.05)$ \\
\hline $\mathrm{p}(-2)$ & -0.42 & 0.27 & -0.31 & 0.24 \\
& $(0.09)$ & $(0.10)$ & $(0.09)$ & $(0.05)$ \\
\hline $\mathrm{u}(-1)$ & 0.13 & 1.50 & -0.05 & 1.57 \\
\hline $\mathrm{u}(-2)$ & $(0.05)$ & $(0.07)$ & $(0.11)$ & $(0.06)$ \\
\hline $\mathrm{c}$ & -0.11 & -0.60 & 0.07 & -0.62 \\
& $(0.04)$ & $(0.07)$ & $(0.11)$ & $(0.06)$ \\
\hline & 0.15 & 0.77 & 0.06 & 0.26 \\
\hline & $(0.22)$ & $(0.24)$ & $(0.19)$ & $(0.11)$
\end{tabular}

Table 1: Estimates from a VAR

Table 1 illustrates the results from estimating a bivariate vector autoregression using $p$ (the logarithm of the $\mathrm{S} \& \mathrm{P} 500$ in wage units) and $u$ (the loga- 
rithm of a logistic transformation of the percentage unemployment rate). The left panel of this table reports regression results for the period from 1953q1 through 1979q3 and the right panel reports results from 1979q4 through 2011q1. Standard errors are in parentheses below each point estimate.

I broke the data in $1979 \mathrm{q} 3$ because there is evidence that many macroeconomic time series behave very differently before and after this date (Beyer and Farmer, 2003, 2007; Clarida, Galí, and Gertler, 2000; Lubik and Schorfheide, 2004; Sims and Zha, 2006). Table 1 shows that instability does not extend to the relationship between unemployment and the stock market. Both equations of this system display remarkable stability before and after 1979. Formal tests reveal that both series can be modeled parsimoniously as integrated series of order 1 , connected by a cointegrating equation.

\section{How to Forecast Unemployment Using Stock Market Data}

The equations describing the dynamics of unemployment and the stock market have remained stable for sixty years. This fact has implications for the ability to forecast future unemployment rates. Forecasts in the period after 1979q3 remain accurate using a forecast equation that was estimated on data from 1953q1 through 1979q3.

$$
\begin{aligned}
& u_{t}=u_{t-1}+0.60 \Delta u_{t-1}-0.27 \Delta p_{t-1}+0.0035 \\
& \text { (0.06) }
\end{aligned}
$$

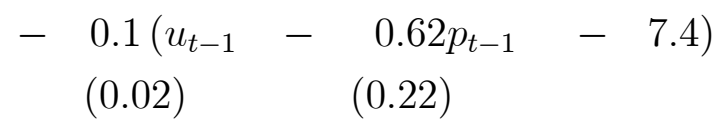




$$
\begin{array}{ccccc}
p_{t}=p_{t-1}+0.13 \Delta u_{t-1}+ & 0.42 \Delta p_{t-1}-0.00095 & \\
(0.06) & (0.09) & (0.0051) & \\
& +0.0084\left(u_{t-1}-0.62 p_{t-1}\right. & - & \\
& & &
\end{array}
$$

Equations (1) and (2) report the coefficient estimates for the unemployment equation and the stock market equation using data from the first sample. These equations use the information that the series are non-stationary but cointegrated to estimate equations in first differences with a cointegrating equation in levels that enters each equation separately. ${ }^{6}$

Equation (1) shows that changes in the unemployment rate are influenced significantly by the lagged unemployment rate and lagged changes in the stock market. Equation (2) shows that similar behavior applies to the S\&P 500. There is evidence of serial correlation in the growth rate of both series. Notice that the point estimate of the coefficient on the cointegrating vector in Equation (1) is significant and equal to -0.1 , implying that unemployment returns to the linear cointegrating equation,

$$
u=0.62 p+7.4
$$

at a rate of $10 \%$ per quarter. Although unemployment is non-stationary, movements in the unemployment rate are tied to movements in the real value of the stock market.

\footnotetext{
${ }^{6}$ These equations were estimated in Eviews using the methods developed by Johansen (1991).
} 


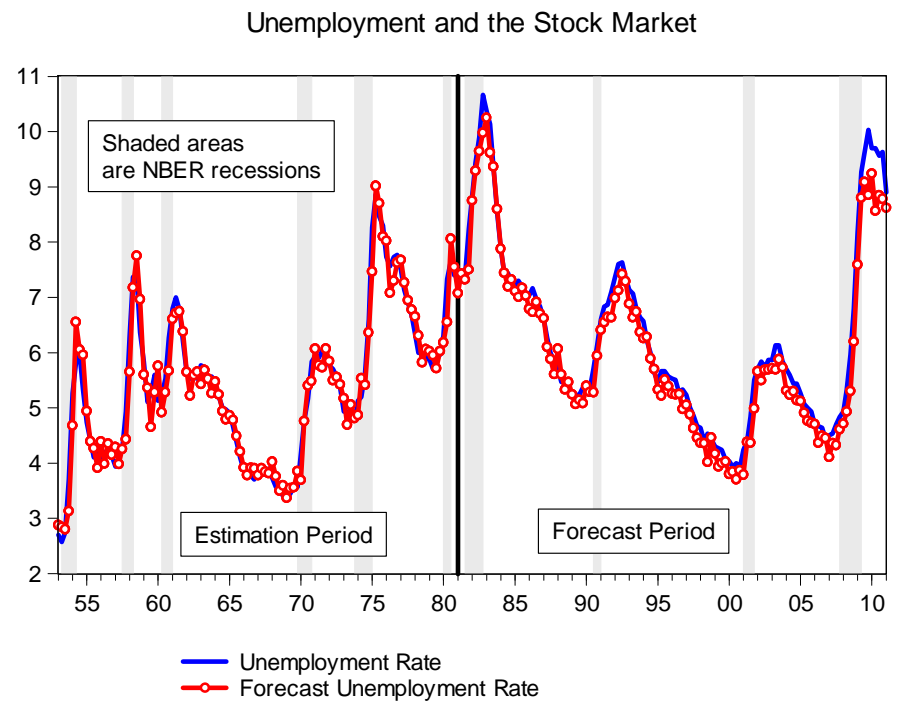

Figure 6: Forecasting Unemployment

The same is not true of the stock market which shows no tendency to revert to the cointegrating vector represented by Equation (3). The coefficient on the cointegrating vector in the unemployment equation is five times its standard error. In contrast, the coefficient on the cointegrating vector in the stock market equation is insignificantly different from zero. Nevertheless, Equation (3) constrains the long-run behavior of the system. Random walk variations in the real value of the stock market cause permanent movements in the unemployment rate.

Figure 6 illustrates the importance of the stability of the connection between the unemployment rate and the stock market over time. This figure plots the actual and one-step-ahead forecast values of the unemployment rate. $^{7}$ The forecast equation, Equation (1), was estimated using data from 1953q1 through 1979q3. Figure 6 demonstrates that the equation from the

\footnotetext{
${ }^{7}$ The forecast is of $100 \bar{u} /(100-\bar{u})$ where $\bar{u}$ is the unemployment rate in percent. I have transformed back in Figure 6 using the inverse transfromation $u=100 \exp (\bar{u}) /(100+$ $\exp (\bar{u}))$.
} 
first period does a remarkably good job of forecasting the unemployment rate over the second period.

\section{The Stock Market and Unemployment: Three Models Compared}

How are we to understand the connection between wealth and unemployment? In this section I will outline three simple models and use a diagram that is suggested by The General Theory to explain each of them.

\subsection{Classical Economics 101}

\subsubsection{The Classical Model Defined}

Consider a model with a large number of identical representative households, each of which lives forever. Households maximize the discounted value of expected utility. Each period the representative household sends a random fraction of household members to the labor market and each of these workers finds a job that pays money wage $w_{t}$. I have added some randomness in labor supply to capture a source of supply fluctuations in employment and GDP.

Households receive utility from the consumption of a unique produced commodity that is manufactured from labor and capital using a Cobb-Douglas technology. There is one unit of non-reproducible capital in the economy. Capital is owned by households and rented to firms for rental rate $r r_{t}$, measured in dollars. The capital good is traded on an asset market for price $p_{k, t}$ and the commodity is traded for dollar price $p_{t}$.

On Figure 7, I have graphed two of the equations of this model. The first is the equation

$$
L_{t}=\exp \left(a_{t}\right)
$$

which determines employment. By assumption employment is entirely gov- 
erned by variations in labor supply and it appears on Figure 7 as a vertical line.

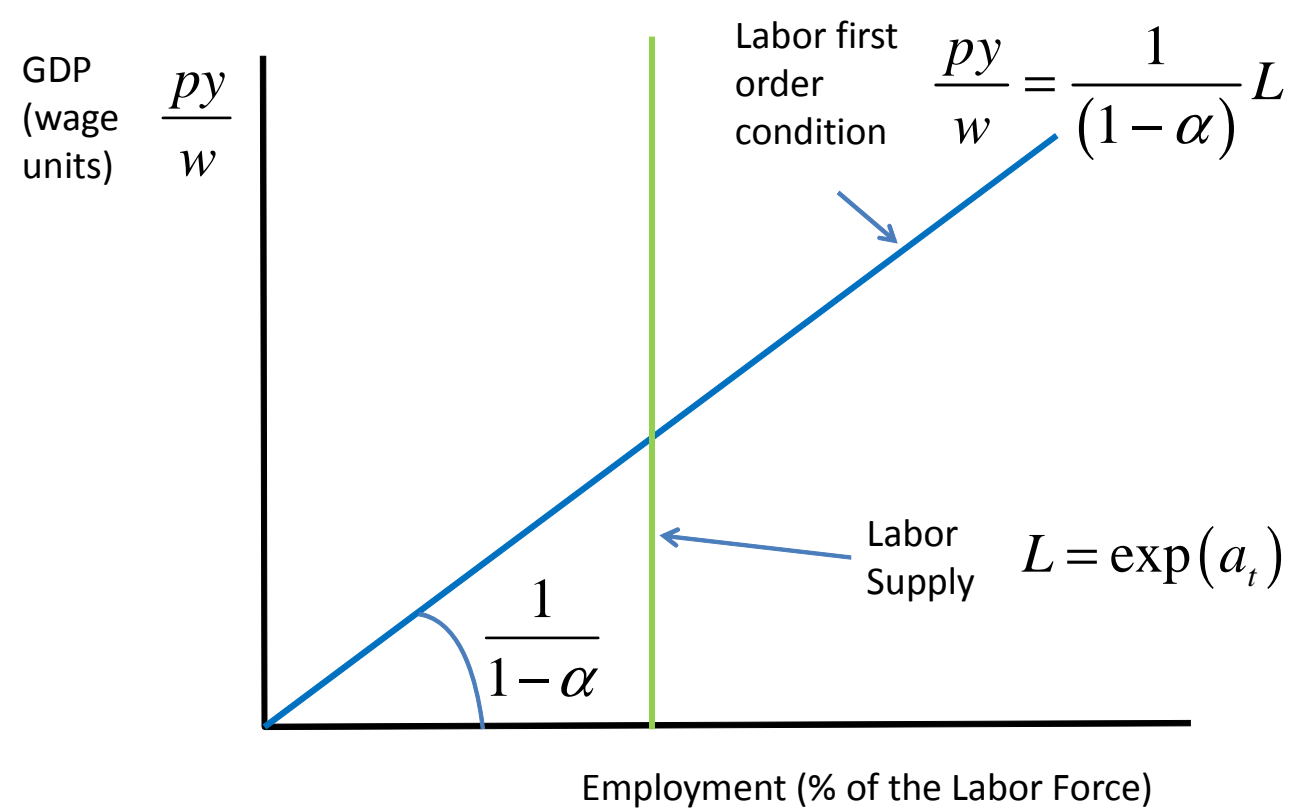

Figure 7: Classical Economics 101

The second equation is the first order condition for the optimal use of labor,

$$
\frac{p_{t} y_{t}}{w_{t}}=\frac{1}{1-\alpha} L_{t}
$$

where $\alpha$ is capital's share of national income. This equation appears on Figure 7 as an upward sloping line. This is an unusual way of representing the equations of a classical model but I have chosen to draw this picture because it enables me to make a direct comparison between classical and Keynesian economics.

The concepts of aggregate demand and supply were described by Keynes (1936, Chapter 3) as two curves that plot the value of GDP, measured in wage units, on the vertical axis of a graph and employment, measured in labor hours, on the horizontal axis. Figure 7 makes clear that GDP, measured in these units, is determined by aggregate labor supply. 


\subsubsection{Implications of the Classical Model for Asset Price Move- ments}

I would like to draw attention to one more implication of the classical model; the connection between GDP and wealth. Simple versions of the classical model imply the following asset pricing equation, where $\theta$ is a parameter that depends on the household's discount rate and on the parameters of technology,

$$
\frac{p_{k, t}}{w_{t}}=\frac{1}{\theta} \frac{p_{t} y_{t}}{w_{t}} .
$$

I have expressed both sides of this equation in wage units by choosing $w_{t}$ as the numeraire. A similar pricing equation will hold in any model in which forward looking agents have rational expectations of future prices. But what are its implications for asset price movements?

Suppose that we see a big drop in the value of the stock market. The classical model would interpret that drop as a fall in $p_{k, t} / w_{t}$. What causes the market to crash? In the classical model, the stock market falls in response to a shock to fundamentals. These include preferences, technology and endowments. In this simple version of the classical model, technology and endowments are held fixed and it follows that a depression must be caused by a fall in $a_{t}$.

During the Great Depression, the U.S. unemployment rate climbed from $3 \%$ to $24 \%$ in the space of three years and it remained above $15 \%$ for a decade. It was the implausibility of attributing this situation to a shock to technology, preferences or endowments that caused Keynes to throw out classical economics and to write The General Theory. 


\subsection{Keynesian Economics 101}

\subsubsection{The Keynesian Model Defined}

The Keynesian explanation of the Great Depression breaks GDP, $Y$, into three components, consumption $C$, investment $I$, and government purchases $G$.

$$
Y \equiv C+I+G
$$

Here I am measuring GDP and its components in wage units. Using this normalization, $Y$ is equal to $p y / w$.

In the simplest formulation of Keynesian theory, investment and government purchases are taken to be exogenous, as represented by equations (8) and $(9)$,

$$
\begin{gathered}
I=\bar{I}, \\
G=\bar{G},
\end{gathered}
$$

and consumption depends on income,

$$
C=a+b Y
$$

Finally, Keynes added an inelastic labor supply curve in which each household supplies a fixed number of hours, $L$, to the labor market.

In this simple model, labor's share of GDP is a constant fraction, $1-\alpha$. Using the definition of $Y$ as nominal GDP divided by the wage, this fact implies the following linear relationship between $Y$ and $L$;

$$
Y=\frac{1}{1-\alpha} L
$$

In a classical model, equilibrium occurs at the intersection of the short-run and long-run aggregate supply curves. Keynes dispensed with the classical 
assumption that households are on their labor supply curves. Removing this condition implies that the long-run aggregate supply curve is a benchmark that defines full employment. Equilibrium occurs at the intersection of the short-run aggregate supply curve with the aggregate demand curve and the horizontal distance from this intersection to the long-run aggregate supply curve defines what Keynes called 'involuntary unemployment'.

\subsubsection{The Keynesian Explanation of the Great Depression}

Keynesians explain the Great Depression as follows. There was an autonomous drop in investor sentiment, caused by animal spirits, that led $\bar{I}$ to fall thereby shifting down the aggregate demand curve in Figure 8. This drop in investment led to an increase in the unemployment rate. The way to restore full employment, according to Keynesians, is to increase government purchases to replace the missing investment expenditure.

Notice that Figure 8 contains three curves to determine the two unknowns; employment and GDP. This poses a dilemma which the post-war Keynesians resolved by arguing that although the intersection of aggregate demand and short-run aggregate supply determines employment and real GDP in the short-run, in the long run, price and wage adjustment would cause all three curves to intersect at the same point.

The adjustment to full employment, according to the Keynesians, comes about through an upward shift of the aggregate demand curve caused either by an increase in investment expenditure or as a wealth effect on consumption. $^{8}$ In either case, eventually, aggregate demand would intersect the ag-

\footnotetext{
${ }^{8}$ The mechanics of adjustment is explained in intermediate economics textbooks, see for example, Mankiw (2010). In "normal times" it involves a response of investment to perceived changes in the real rate of interest. In periods when the interest rate is effectively zero (as it is in the current recession) this mechanism may be ineffective. There is, however, an alternative adjustment mechanism that operates through a wealth effect on consumption. This effect was pointed out by Don Patinkin in his seminal work, Money Interest and Prices (1956), but it originated with Pigou's (1943) article in the Economic Journal.
} 
gregate supply curve at full employment. I have labeled this as "long-run aggregate supply" on Figure 8.

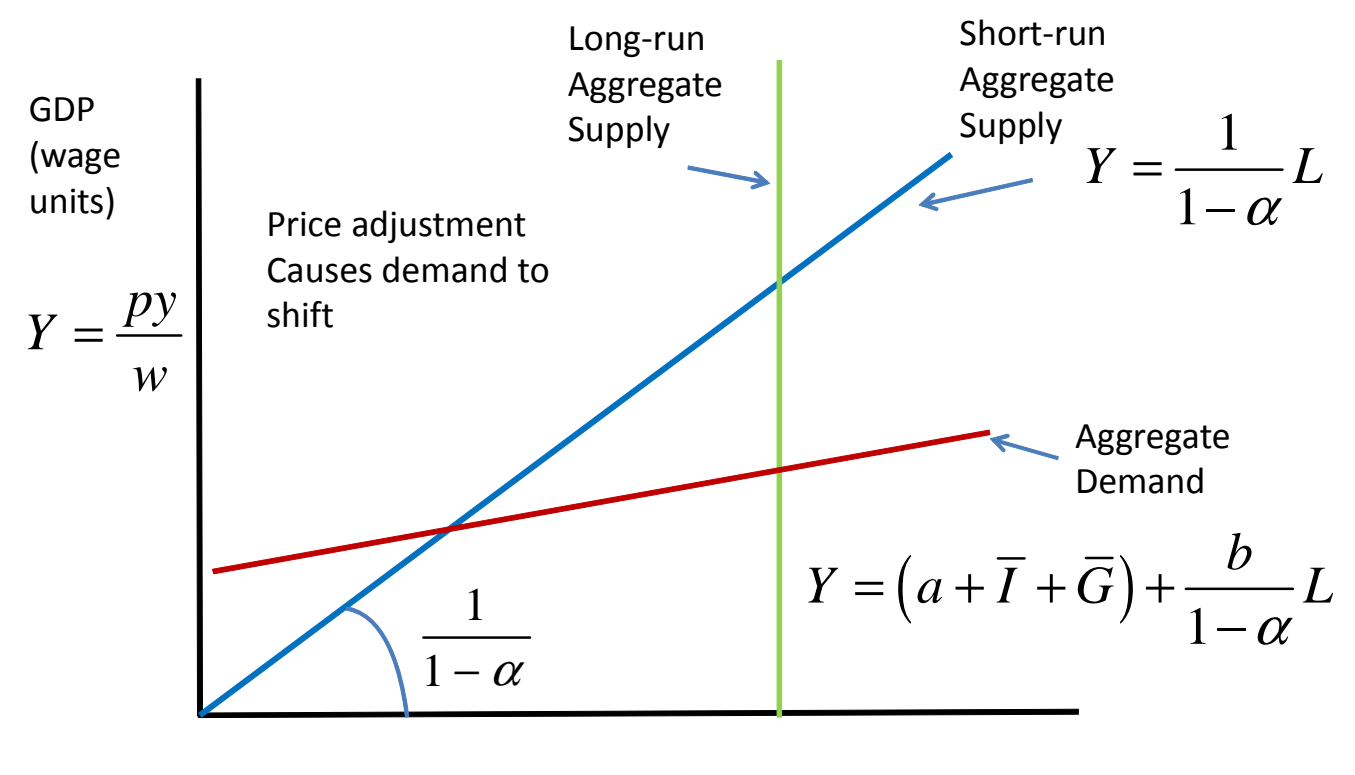

Employment (\% of the Labor Force)

Figure 8: Keynesian Economics 101

If the system is eventually self-adjusting then why would the government need to intervene? The Keynesians argued that the price adjustment required to restore full employment might take a very long time and would likely involve considerable lost output if unemployment were to remain high for an extended period. A more effective remedy would be for government to replace the lost investment by increasing government expenditure. This would shift up the aggregate demand curve on Figure 8 and restore full employment more quickly.

\subsection{Farmerian Economics 101}

\subsubsection{Farmerian Economics Defined}

In a series of recent papers Farmer (2009, 2010a, 2011) I have reinterpreted The General Theory by going back to the classical model and adding an 
explicit theory of search. In that work I showed that, in a search market, firms face an externality that alters the production function of an individual firm. Suppose, for example, that output is produced by many firms each operating the technology

$$
y=A L^{1-\alpha} K^{a},
$$

where $y$ is output in physical units, $K$ is capital, $L$ is labor and $A$ is a productivity parameter. I showed in Farmer (2009), that labor market search implies that the productivity parameter $A$, is related to aggregate employment by the following expression,

$$
A=(1-\bar{L})^{1-\alpha},
$$

where $(1-\bar{L})$ is the aggregate unemployment rate. All other aspects of my model look very neoclassical. Profit maximizing firms take wages and prices as given, but their productivity depends on aggregate labor market activity.

Standard models of search assume that, when a firm meets a worker, they bargain over the wage. ${ }^{9}$ I see no reason to add this equation to the model and instead, I replace the Nash-bargaining equation by the assumption that employment is demand determined. Firms sell as much output as is demanded. By dropping the Nash-bargaining equation I arrive at a model in which any unemployment rate is consistent with profit maximizing behavior and rational forward looking households.

\subsubsection{Closing Farmer's Model with a Belief Function}

The model I have developed can be closed in a number of ways. In most of my work, I have used the representative agent assumption and it is that way of closing the model that I have depicted in Figure 9.

Since the asset pricing equation holds in my work, as it does in the clas-

\footnotetext{
${ }^{9}$ See, for example, the survey of search literature by Rogerson, Shimer, and Wright (2005).
} 
sical model, there is a connection between the value of asset prices and aggregate GDP. I have depicted that relationship in Figure 9 as a horizontal line whose position depends on the value of the stock market. Equation (14) captures that connection.

$$
Y_{t}=\theta \frac{p_{k, t}}{w_{t}} .
$$

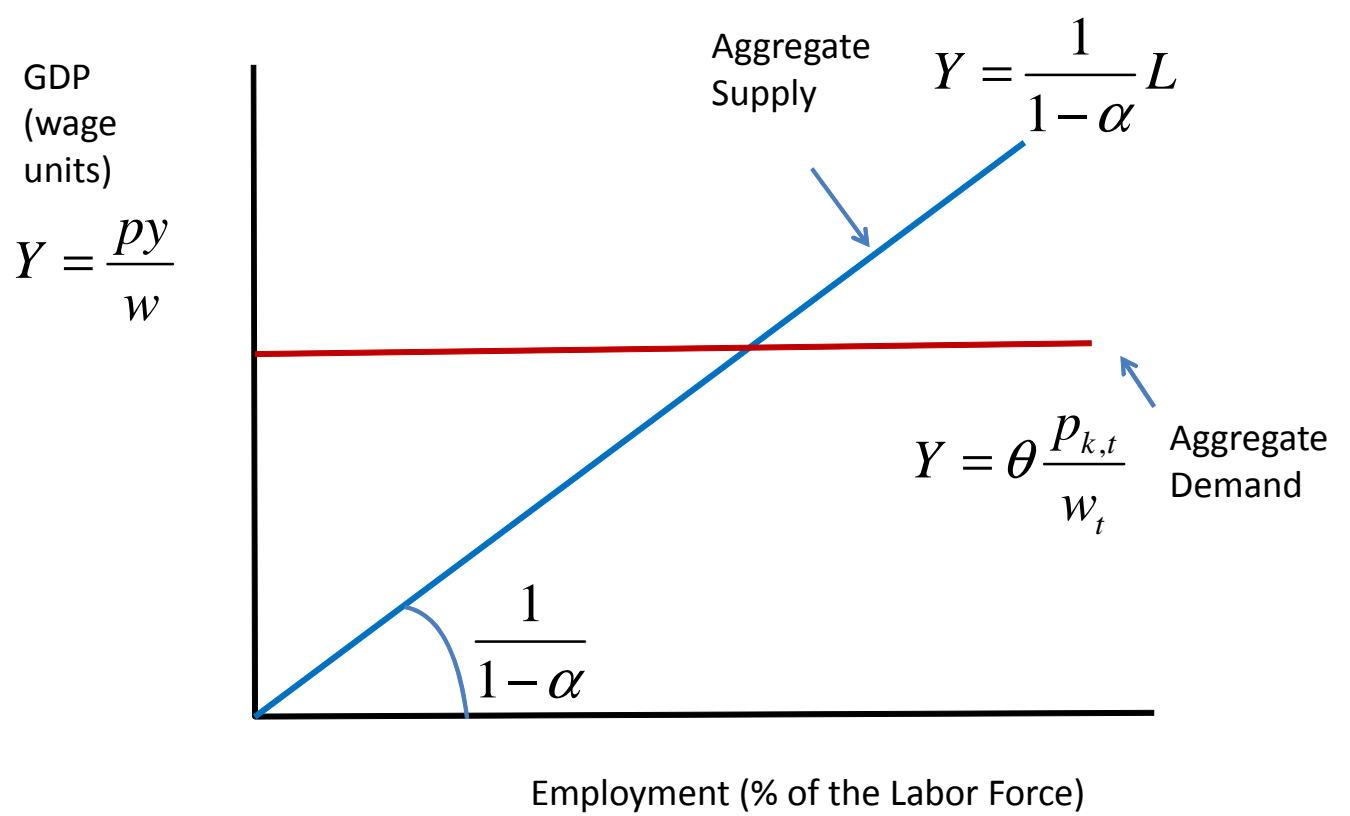

Figure 9: Farmerian Economics 101

Although Equation (14) is identical to Equation (6) from the classical model, in my work the direction of causation is reversed. Whereas in the classical model, $Y_{t}$ determines $p_{k, t}$, I assume instead that asset prices evolve independently and are driven by self-fulfilling beliefs. I model the evolution of those beliefs with an equation that I call the belief function.

A simple form of the belief function that is consistent with the estimates I reported in Equation (2) is described in equations (15) and (16).

$$
E_{t}\left[\frac{p_{k, t+1}}{w_{t+1}}\right] \equiv X_{t},
$$




$$
\log X_{t}=\log X_{t-1}+f\left(\Delta U_{t-1}\right)+\varepsilon_{t} .
$$

In these equations, $X_{t}$ represents beliefs about the future real value of the stock market. This variable is highly persistent and shocks to $X_{t}$ are permanent. My formulation of the belief function also allows feedback from the observed unemployment rate $U_{t-1}$ to influence beliefs. The term $\varepsilon_{t}$ represents a random shock to beliefs that arises from the animal spirits of market participants.

\subsubsection{The Belief Function is Consistent with Rational Expecta- tions}

It is important to recognize that Equation (15) is not an alternative to the rational expectations assumption. It is in addition to it. The rational expectations assumption is captured by equations (17) and (18),

$$
\begin{gathered}
\frac{p_{k, t}}{w_{t}}=E_{t-1}\left[\frac{p_{k, t}}{w_{t}}\right]+w_{t}, \\
E_{t-1}\left[w_{t}\right]=0 .
\end{gathered}
$$

The term $\varepsilon_{t}$ that enters Equation (16) is a fundamental shock to beliefs whereas $w_{t}$ is a non-fundamental forecast error. In a rational expectations equilibrium, $w_{t}$ will be a function of $\varepsilon_{t}$ as shocks to beliefs about the future value of the stock market cause the $t-1$ expectation of $p_{k, t} / w_{t}$ to deviate from its realization.

How can beliefs be driven by an independent fundamental mechanism and yet still be rational? One answer to this question is that the belief function is an equilibrium selection mechanism that resolves a potential indeterminacy of equilibrium by coordinating the expectations of agents. It represents what George Soros has called the "mood of the markets". Because there are many underlying equilibria that are consistent with rational expectations, so there are many possible belief functions that can select amongst these equilibria. 
I believe that a fruitful start to belief-driven models is to take the belief function as an object to be determined empirically.

\subsubsection{Farmer's Model Compared to Keynesian Economics}

The diagram that I have called Farmerian Economics 101 looks remarkably like the Keynesian diagram, Figure 8. It differs in two critical respects. First, I have not represented the vertical full employment line on Figure 9 since it plays no role in my explanation of events. My work explains high and persistent unemployment as an equilibrium phenomenon. There is an optimum unemployment rate that is achieved by allocating workers between the activities of search and production. ${ }^{10}$ But there is no tendency for the model to converge back towards this optimal unemployment rate and it does not make sense to talk about the natural rate of unemployment.

The second difference of my model from Keynesian economics is that the position of the aggregate demand curve does not depend on government expenditure. It depends on the value of the stock market. I have chosen that way of closing the model because my reading of the empirical evidence is that private consumption is crowded out by government purchases. When the government spends more, households spend less. In Farmer's model, no amount of government fiscal stimulus can permanently restore full employment.

The word "permanently" is an important qualifier. I am not asserting that fiscal stimulus is always ineffective. In joint work with Dmitry Plotnikov (Farmer and Plotnikov, 2010), we showed that a temporary unanticipated fiscal stimulus can reduce unemployment in the short run. But it cannot solve the long-term problem. That requires private agents to revise their forecasts of the values of houses, factories and machines. The key to restoring full employment is to increase the real value of wealth and, in my view, that can and should be achieved through direct government intervention in the

\footnotetext{
${ }^{10}$ For the details of this argument, see Farmer (2009).
} 
stock market.

\section{Why I am Not a Classical Economist}

The fact that there is a relationship between unemployment and the value of the stock market does not imply that this relationship is causal. It is difficult, if not impossible, to disprove the thesis that the stock market is simply accumulating the knowledge of market participants. According to one classical interpretation of events that led to the Great Recession, traders in 2008 foresaw that there would be a big drop in dividend payments to private companies as a consequence of high future unemployment. The anticipated increase in unemployment was caused by a change in the regulatory environment which, it is asserted, became much more hostile to business following the Lehman bankruptcy.

That account is implausible. The change in the regulatory framework since 2008 does not seem large enough to account for a permanent increase in the unemployment rate of $5 \%$. It is true that politicians in the U.S. and Europe have added to the uncertainty, but the magnitude of the drop in employment is hard to square with the explanation that firms are concerned about possible future tax increases or the fear of an increase in bureaucratic red tape.

An alternative explanation of the crisis that is widely held by central bankers is that firms are liquidity constrained. ${ }^{11}$ It was the liquidity constraint explanation of the recession that caused central banks throughout the world to flood the financial system with cheap money. As a direct consequence of Fed policy, U.S. businesses are now awash with credit and commercial banks are holding in excess of $\$ 2,000 \mathrm{~b}$ in excess reserves with the Federal Reserve. In light of these facts, it seems unlikely that the unavailability of

\footnotetext{
${ }^{11}$ This view has dominated Fed policy since the inception of the crisis. See for example, the speech by Chairman Bernanke (2008).
} 
credit is currently constraining U.S. corporations from creating jobs.

\subsection{The Stock Market Crash of 2008 Caused the Great Recession}

I believe that there is an alternative more credible explanation of the connection between stock market wealth and unemployment in which an apparent liquidity crisis is a symptom, rather than the cause of the recession. That explanation involves the shift from a high employment to a low employment equilibrium as households and firms re-evaluated their beliefs about the value of U.S. wealth.

To make the case that a drop in stock market wealth can cause an increase in the unemployment rate, there must be a plausible transmission mechanism from one to the other. In my work, that mechanism operates through aggregate demand.

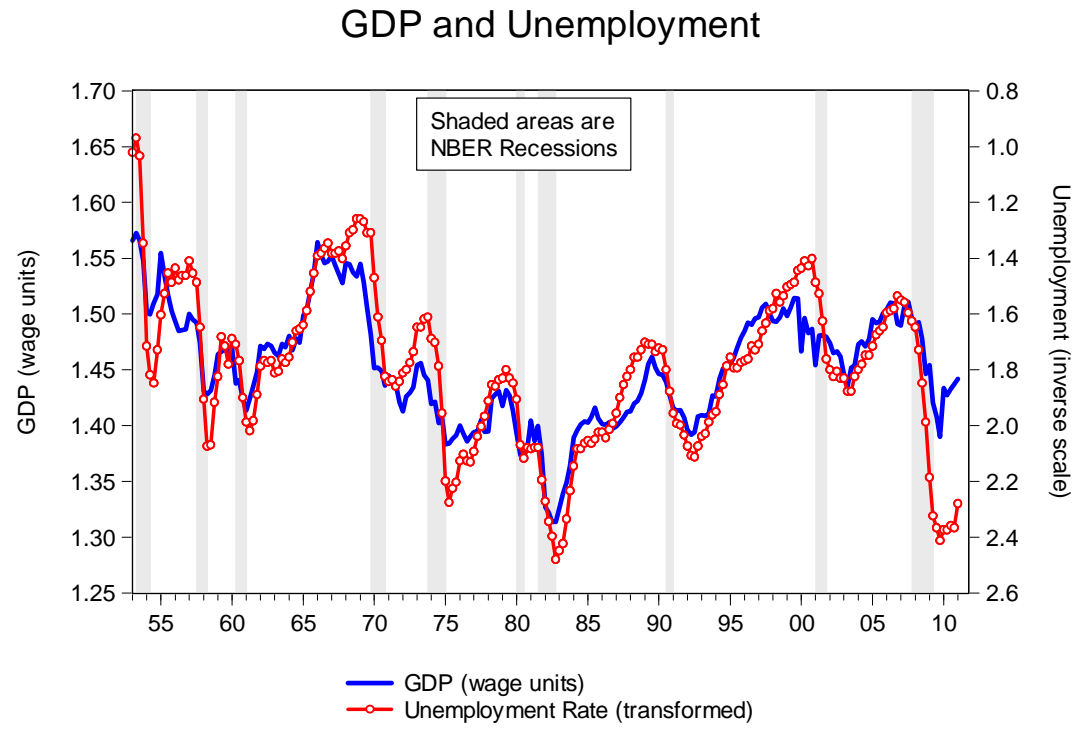

Figure 10: GDP and Unemployment 
Keynesians draw attention to Okun's law; a relationship between detrended real GDP and the unemployment rate. Figure 10 depicts Okun's law for post-war data. It plots GDP measured in wage units and the log of a logistic transform of the unemployment rate for the period from 1953q1 to 2011 1.

In Farmer's model economics, Okun's law holds in the data because movements in the unemployment rate are caused by movements in aggregate demand. It is the empirical counterpart of the aggregate supply curve in Figure 9. To construct an explanation of the causes of unemployment we must build a theory of how each of the components of aggregate demand moves over time.

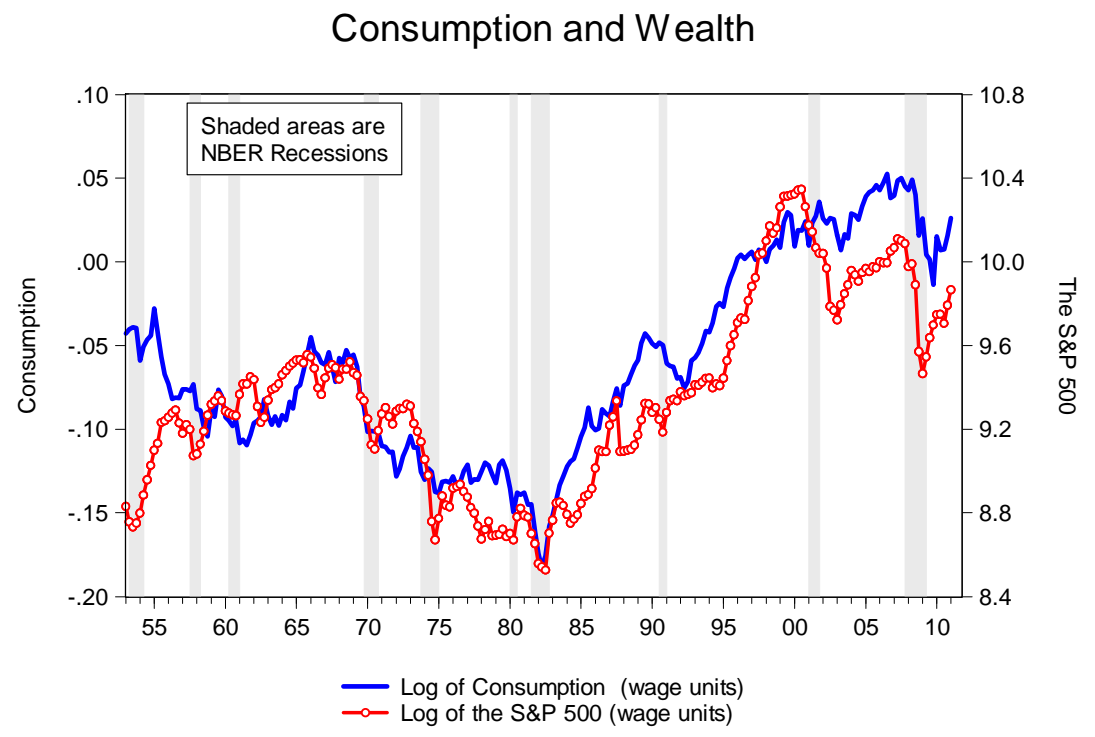

Figure 11: Consumption and Wealth

In a closed economy, GDP consists of consumption, investment and government purchases. ${ }^{12}$ Although there is some evidence of a high frequency correlation between the stock market and investment, particularly in the two

\footnotetext{
${ }^{12}$ Even a large economy like the U.S. is not closed. But the size of net exports is relatively small and I will ignore them in this discussion.
} 
most recent recessions, investment fluctuations are not responsible for permanent shifts in the unemployment rate. Investment, measured in wage units, is a stationary series (Farmer, 2010b). Permanent shifts in the unemployment rate are closely associated with permanent movements in consumption.

Figure 11 shows the relationship between consumption and stock market wealth in post-war data. Formal tests on these data confirm that the log of consumption and the log of the S\&P 500, both in wage units, are each non-stationary but cointegrated.

\subsection{Beliefs Drive Aggregate Demand}

In my work, confidence, represented by Equation (16), is an independent driving force of business cycles. I call Equation (16) a belief function: it describes the way that households and firms form expectations of the future. ${ }^{13}$ The belief function is a fundamental that has the same methodological status as preferences, technology and endowments. As agents revise their beliefs, shocks to those beliefs influence the real value of wealth. A large negative shock to beliefs results in a large drop in wealth that causes households and firms to reduce their consumption expenditures. The drop in stock market wealth also influences investors who will not purchase new factories and machines if they believe that the value of their existing capital may fall further.

Beliefs are highly persistent and it is this persistence that accounts for extended periods of high unemployment like the Great Depression and the Great Recession. After a stock market crash, households reduce their consumption expenditure. The associated fall in aggregate demand causes businesses to layoff workers and that generates a further wealth effect as newly unemployed households experience a fall in the value of their expected future

\footnotetext{
${ }^{13}$ I have described how a belief function can be used to close a macroeconomic model in Farmer (2011). In (Farmer, 2010a) I incorporate a belief function into a fully specified model of inflation, unemployment and interest rates and I estimate the model on U.S. data.
} 
earnings. There is a multiplier effect, similar to the Keynesian multiplier, but it operates through wealth and not through income.

\section{Why I am not a Conventional Keynesian Economist}

My skepticism for the Keynesian explanation of the multiplier is based on empirical evidence. The Keynesian multiplier relies on the existence of a stable relationship between aggregate income and aggregate consumption. That is the basis behind the Keynesian explanation of unemployment popularized by Samuelson in his (1948) textbook. But the facts uncovered in research in the 1950s and 1960s (Modigliani and Brumberg, 1954; Friedman, 1957; Ando and Modigliani, 1963) show that consumption depends not on income but on wealth.

In their definitive survey of crowding out in macroeconomic models, Carlson and Spencer (1975) discuss the possibility that consumption may be crowded out, in a classical model, as a consequence of the fact that GDP is fully determined by preferences, endowments and technology. As government increases its share of GDP, consumers recognize that the implicit value of their future wealth has fallen since taxes must eventually rise to pay for additional interest on the accumulated debt.

\subsection{Beliefs are the New Fundamental}

The same mechanism is at work in my model. GDP is determined by preferences, technology and endowments. But in my work, beliefs appear as an additional fundamental. Unless one of the four fundamental determinants of aggregate demand changes in response to a change in government purchases, another component of GDP must be crowded out. 

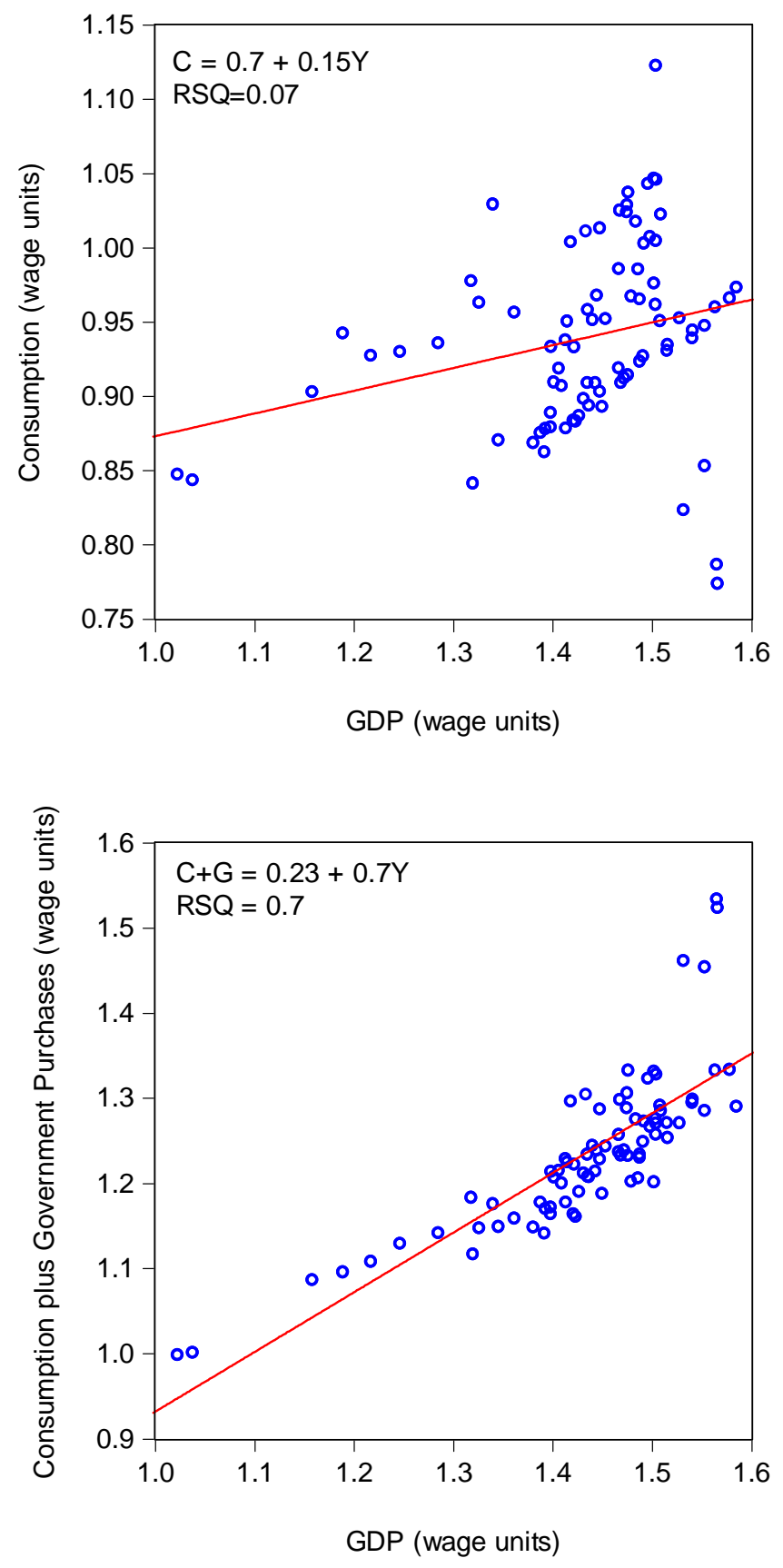

Figure 12: Two Versions of the Consumption Function 
One is tempted to argue that this is an interesting curiosity. But what is the evidence for crowding out in the data? The upper panel of Figure 12 plots real GDP on the horizontal axis and private consumption expenditure on the vertical axis. The data is annual from 1929 through 2010 and both series are expressed in wage units and have been divided by a measure of the labor force. The regression line through these points has an $R^{2}$ of 0.07 . The figure demonstrates that consumption as a function of income has not remained stable over this period.

The lower panel of Figure 12 plots real GDP on the horizontal axis against a measure of consumption plus government purchases on the vertical axis. The regression line on this panel has an $R^{2}$ of 0.7 . There is much more support for the stability of this relationship than for the Keynesian consumption function in the upper panel.

How is one to interpret these data? As a matter of definition, one can attribute the instability of the consumption function to shifts in the intercept; the parameter ' $a$ ' in Equation (10). The fact that the $C+G$ function on the lower panel of the figure remains relatively stable, implies that increases in $G$ are offset by corresponding reductions in ' $a$ '. It is a short step to argue that consumers chose to increase their saving in response to an increase in government purchases and it follows that an increase in government spending is unlikely to be an effective way of restoring aggregate demand.

\section{Conclusion}

The General Theory was an important book that had a profound impact on the way that we perceive the role of government in the economy. It introduced the idea that market economies are not inherently self-stabilizing and it suggested new regulatory mechanisms to help maintain full employment. In my view, that basic idea is correct. But The General Theory was a work in progress and the details were never worked out either by Keynes himself 
or by his successors.

In the late 1970s the economics profession gave up on Keynesian economics. Our disenchantment occurred for a reason. The occurrence of high inflation and high unemployment together was inconsistent with the way that post-war Keynesians interpreted Keynesian economics. But that in itself would not have been enough to cause the paradigm shift that was ushered in with the rational expectations revolution (Lucas Jr., 1972). There was a fundamental theoretical incompleteness in the The General Theory. Keynes did not provide a microeconomic foundation to his decision to discard the classical labor supply equation. My work does.

After WWII, Keynesian economics became synonymous with the idea that prices are sticky. That view was introduced to several generations of economists who were schooled on Paul Samuelson's 1948 textbook. My work provides an alternative reconciliation of Keynesian economics with microeconomic theory. My interpretation of Keynesian economics does not rely on sticky prices. That, in itself, does not invalidate the Keynesian policy conclusion that deficit spending is the right way to restore full employment. One could accept my explanation of the reasons for unemployment but still believe that a large fiscal expansion is the right way to solve the problem. I have rejected that approach because of my interpretation of the evidence provided by Friedman (1957) in his work on permanent income.

Friedman argued that individuals are forward looking in their behavior and that consumption depends not on transitory income, but on permanent income or wealth. That fact has important implications for the ability of fiscal policy to influence economic activity since it implies that government spending will crowd out an equal amount of private spending. My reading of the evidence is that crowding out occurs in practice and it is that feature of the data that leads me to stress asset market intervention as a potential policy resolution to the problem of high and persistent unemployment. 


\section{References}

Ando, A., and F. Modigliani (1963): "The "Life Cycle" Hypothesis of Saving: Aggregate Implications and Tests," American Economic Review, $53(1), 55-84$.

BALL, L. (1999): "Aggregate Demand and Long-Run Unemployment," Brookings Papers on Economic Activity, 2, 189-236.

Bernanke, B. S. (2008): "Remarks to the Federal Reserve Bank of Atlanta Conference, Sea Island, Georgia," http://www.federalreserve.gov/newsevents/speech/bernanke20080513.htm.

Beyer, A., And R. E. A. Farmer (2003): "Identifying the Monetary Transmission Mechanism Using Structural Breaks," European Central Bank Working Paper Series, No. 275.

- (2007): "Natural Rate Doubts," Journal of Economic Dynamics and Control, 31(121), 797-825.

Blanchard, O. J., and L. H. Summers (1986): "Hysterisis and the European Unemployment Problem," in NBER Macroeconomics Annual, vol. 1, pp. 15-90. National Bureau of Economic Research.

(1987): "Hysterisis in Unemployment," European Economic Review, 31, 288-295.

Carlson, K. M., and R. W. Spencer (1975): "Crowding Out and its Critics," Federal Reserve Bank of St. Loius, pp. 2-16.

Clarida, R., J. Galí, and M. Gertler (2000): "Monetary Policy Rules and Macroeconomic Stability: Evidence and Some Theory," Quarterly Journal of Economics, 115(1), 147-180. 
FArmer, R. E. A. (2008): "Old Keynesian Economics," in Macroeconomics in the Small and the Large, ed. by R. E. A. Farmer, chap. 2, pp. 23-43. Edward Elgar, Cheltenham, UK.

- (2009): "Confidence, Crashes and Animal Spirits," NBER WP no. 14846, Economic Journal (forthcoming).

(2010a): "Animal Spirits, Persistent Unemployment and the Belief Function," NBER Working Paper no. 16522 and CEPR Discussion Paper no. 8100., forthcoming in Frydman and Phelps (2012).

- (2010b): Expectations, Employment and Prices. Oxford University Press, New York.

(2010c): How the Economy Works: Confidence, Crashes and Selffulfilling Prophecies. Oxford University Press, New York.

- (2010d): "How to Reduce Unemployment: A New Policy Proposal," Journal of Monetary Economics: Carnegie Rochester Conference Issue, $57(5), 557-572$.

- (2011): "Animal Spirits, Rational Bubbles and Unemployment," NBER Working Paper $1713 \%$.

- (December 30th 2008): "How to Prevent the Great Depression of 2009," Financial Times, Economists' Forum, http://blogs.ft.com/economistsforum/2008/12/how-to-prevent-thegreat-depression-of-2009/.

Farmer, R. E. A., And D. Plotnikov (2010): "Does Fiscal Policy Matter? Blinder and Solow Revisited," NBER Working Paper number 16644.

Fitoussi, J.-P., D. Jestaz, E. S. Phelps, and G. Zoega (2000): "Roots of the Recent Recoveries: Labor Reforms or Private Sector Forces," Brookings Papers on Economic Activity, 1, 237-312. 
Friedman, M. (1957): A Theory of the Consumption Function. Princeton University Press, Princeton, N.J.

Frydman, R., And E. Phelps (2012): Foundations for a Macroeconomics of the Modern Economy. Princeton University Press, Princeton N.J.

Galí, J. (2008): Monetary Policy, Inflation, and the Business Cycle: An Introduction to the New Keynesian Framework. Princeton University Press.

Galí, J., And M. Gertler (1999): "The Science of Monetary Policy: a New Keynesian Perspective," Journal of Economic Literature, XXXVII, 1661-1707.

Gomme, P., B. Ravikumar, and P. Rupert (2011): "The return to capital and the business cycle," Review of Economic Dynamics, 14, 262278.

Hodrick, R. J., and E. C. Prescott (1997): "Post-war U.S. business cycles: A descriptive empirical investigation.," Journal of Money Credit and Banking, 29, 1-16.

Hoon, T., And E. S. Phelps (1992): "Macroeconomic Shocks in a Dynamized Model of the Natural Rate of Unemployment," American Economic Review, 82(4), 889-900.

Johansen, S. (1991): "Estimation and Hypothesis Testing of Cointegration Vectors in Gaussian Vector Autoregreeive Models," Econometrica, $59,1551-1580$.

Keynes, J. M. (1936): The General Theory of Employment, Interest and Money. MacMillan and Co., London and Basingstoke, 1973 edition published for the Royal Economic Society, Cambridge. 
Lettau, M., and S. C. Ludvigson (2004): "Understanding Trend and Cycle in Asset Values: Reevaluating the Wealth Effect on Consumption," American Economic Review, 94(1), 276-299.

(2011): "Shocks and Crashes," NYU Mimeo, Lettau, Martin and STdney C. Ludvigson.

Lubik, T. A., And F. Schorfheide (2004): "Testing for Indeterminacy: An Application to U.S. Monetary Policy," American Economic Review, 94, 190-219.

LuCAS JR., R. E. (1972): "Expectations and the Neutrality of Money," Journal of Economic Theory, 4, 103-124.

Mankiw, N. G. (2010): Macroeconomics. Worth, New York, Seventh Edition.

Modigliani, F., and R. Brumberg (1954): "Utility analysis and the consumption function: An interpretation of cross-section data," in PostKeynesian Economics, ed. by K. Kurihara. Rutgers University Press.

Patinkin, D. (1956): Money Interest and Prices. The MIT Press, Cambridge, Massachusetts, second abridged edn.

Phelps, E. S. (1994): Structural Slumps. Harvard University Press, Cambridge, Mass.

- (1999): "Behind this Structural Boom: the Role of Asset Valuations," American Economic Review Papers and Procedings, 89(2), 63-68.

PIGOU, A. C. (1943): "The Classical Stationary State," Economic Journal, $53,343-351$.

Rogerson, R., R. Shimer, and R. Wright (2005): "Search-Theoretic Models of the Labor Market: A Survey," Journal of Economic Literature, 43, 959-988. 
Samuelson, P. A. (1948): Economics: an Introductory Analysis. McGraw Hill, New York.

Sims, C. A., And T. Zha (2006): "Were There Regime Switches in US Monetary Policy?," The American Economic Review, 96(1), 54-81. 